\title{
Stringency of government responses to COVID-19 and initial results: A comparison between five European countries and Turkey
}

\section{Ülkelerin COVID-19'a karşı aldıkları önlemlerin sertlikleri ve ilk sonuçları: Beș Avrupa ülkesi ve Türkiye arasında bir karșılaștırma}

\author{
Hakan KAÇAK', Mustafa Said YILDIZ²
}

\section{ABSTRACT}

Objective: COVID-19, having no treatment and medical intervention strategy other than supportive treatment, necessitated prevention and containment measures. Quarantines, lock-downs of commercial places, school closures and many other types of interventions converged as cases and the number of deaths has increased. Causality and linkage between measures and their effects have become a concern. This study aims to compare the country policies (Italy, Spain, France, United Kingdom, Germany and Turkey) in terms of stringency levels and the dates interventions put into effect for containment of the pandemic and explore its effects on numbers of cases and deaths.

Methods: The Government Response Stringency Index (GRSI), which is created to measure stringency of government measures against COVID-19 was used for the comparisons. In order to compare countries' policies and their effects on case and death statistics, we initially aggregated the stringency data of countries and compiled them with logistic numbers of cases and deaths. Additionally, variation between country responses could be more apparent by decomposing the total stringency score to individual policy components.

\section{ÖZET}

Amaç: COVID-19, destek tedavilerinden bașka müdahale stratejisi bulunmaması nedeniyle engelleme ve baskılama önlemlerine gerek duyulmasına sebep oldu. Karantinalar, ticari mekânlar için kapatmalar, okul ara vermeleri ve diğer müdahale tipleri vaka ve ölüm sayılarının artmasıyla beraber tüm ülkeler için standart hale geldi. Önlemler ve etkileri arasındaki bağlantı ve sebep-sonuç ilișkisi bir kaygı nedeni haline geldi. Bu çalıșmada, seçilen ülkelerin (İtalya, Ispanya, Fransa, Birleșik Krallık, Almanya ve Türkiye) pandemiyi engelleme politikalarının sertlik dereceleri ve müdahalelerin ilk uygulamaya konuldukları tarihler bakımından karșılaștııııması ve bunun vaka ve ölümler üzerindeki etkisinin araștırılması amaçlanmıştır.

Yöntem: Ülkeler arası karșılaștırma için COVID-19 karșısında hükumet önlemlerinin sertliğini ölçmek amaçlı geliștirilen İdari Tedbir Sıkılık Endeksi kullanılmıștır. Ülkelerin politikalarını ve bunun vaka ve ölüm istatistikleri üzerindeki etkilerini karșılaștırmak için önce ülke sıkılık verilerini zaman serileri halinde toplulaștırdık ve vaka ve ölüm sayıları ile bir araya getirdik. Ayrıca, toplam sıkılık skorunun tekil politika bileșenlerine ayrıștırılması ile ülke tedbirleri arasındaki değişkenlik daha görünür hale geldi.

'Ministry of Health, Turkey

${ }^{2}$ Ministry of Health, Internal Audit Department, Turkey

İletişim / Corresponding Author : Mustafa Said YILDIZ

Sağlık Bakanlığı Ek Binası M. Esat Bozkurt Cad. Umut Sok. No: 19 - Ankara - Türkiye

E-posta / E-mail : msaid.yildiz@saglik.gov.tr

Geliş Tarihi / Received : 11.05 .2020 Kabul Tarihi / Accepted : 21.06.2020

DOI ID : 10.5505/TurkHijyen.2020.60487

Kaçak H, Yıldız MS. Stringency of government responses to COVID-19 and initial results: A comparison between five European countries and Turkey. Turk Hij Den Biyol Derg, 2020; 77(2): 233-242 
Results: Number of cases and deaths, intervention stringency levels and components of policies were compared. The number of cases per million population was higher than other countries for Spain and Italy despite their more stringent measures. Turkey had the least cases per million value with relatively less stringent policies. The number of deaths per million population and stringency levels was higher for French, Italy, and Spain. Turkey and Germany seem to control at least the number of deaths with less stringent measures. United Kingdom had the least stringent scores but a considerable number of deaths. After close investigation of countries' stringency patterns with first case dates, it can be observed that Turkey is diverse from any other country, having taken action for any type of intervention before or concurrent with the first case, as the other countries had taken the measures weeks after their first cases.

Conclusion: Inconsistency of perspective towards the outbreak and delay for implementation led European countries to take strict precautions against COViD-19 for longer period for the next phases of intervention. Turkey took action earlier than other nations before the number of cases increased, and reached less number of cases and deaths with less stringent measures. Comparison between intervention stringency levels and policy enforcement rapidity of selected countries highlighted the importance of implementation of measures on time.

Key Words: Pandemic, health policy, government responses, COVID-19, stringency of responses, Turkey, European countries, Stringency index
Bulgular: Vaka ve ölüm sayıları, tedbir sertlik seviyeleri ve politika bileșenleri arasında karșılaștırma yapıldı. Milyonda vaka sayıları İspanya ve İtalya'da daha sert tedbirler uygulanmasına rağmen daha yüksekti. Türkiye görece daha az sertlikte önlemler almasına karşılık en az milyonda vaka sayısına sahipti. Fransa, İtalya ve İspanya'nın milyonda ölüm sayıları ve politika sertlik seviyeleri daha yüksekti. Türkiye ve Almanya'nın ölümleri daha az sertlikte tedbirlerle kontrol ettikleri görülüyordu. Birleșik Krallık en düșük sertlikte skorlara fakat kayda değer ölüm sayısına sahipti. Ülkelerin politika sertlik paternleri ilk vakaları ile birlikte daha yakından incelendiğinde, diğer ülkeler ilk vakalarından haftalar sonra tedbirleri uygulamaya koyarken Türkiye'nin her bir müdahale türünü ilk vaka ile aynı anda veya daha önce bașlatması ile diğer ülkelerden ayrıștığı görülmüștür.

Sonuç: Salgına karșı yaklaşımlarda tutarsızlık ve uygulamalarda gecikmeler Avrupa ülkeleri için müdahalenin sonraki fazlarında daha sert önlemleri daha uzun süre alma gereksinimine neden olmuștur. Türkiye vaka ve ölüm sayıları yükselmeden önce seçilen diğer ülkelerden daha erken tarihte aksiyon alabilmiștir. Seçilen ülkelerin müdahale sertlik dereceleri ve politikaları uygulamaya koyma hızı arasındaki karșılaștırma, politika önlemlerini zamanında uygulamanın önemini vurgulamaktadır.

Anahtar Kelimeler: Pandemi, sağlık politikası, idari tedbirler, COVID-19, tedbirlerin sertliği, Türkiye, Avrupa ülkeleri, Politika Sertlik Endeksi

\section{INTRODUCTION}

After pneumonia cases emerged in Wuhan, Hubei, China; sequences analysis indicated a novel coronavirus. Until the beginning of February, several thousands of cases were confirmed in other provinces of China and the first cases for Thailand, Japan, South Korea, and USA (1).
Defining as zoonotic infection with low to moderate mortality rate, the disease was officially named as Coronavirus Disease-2019 (COVID-19) by World Health Organization on 11.02.2020. Two days after Iran, which confirmed the first case in 19.02.2020 and became the epicenter of the outbreak for the 
Middle East (2), Italy confirmed its first case and could not prevent the exponential growth of the number of cases and deaths (3).

In 13.03.2020, two days after labeling the outbreak as a pandemic, WHO named Europe as the new epicenter of the outbreak, while Italy had the most cases $(15,113)$ outside China, followed by Spain $(4,334)$ and Germany $(3,156)$ (4). Europe had the number of deaths surpassing 100.000 for 19.04.2020 despite different types of measures which had taken by countries. Finally, Turkey announced the first COVID-19 case of the country in 13.03.2020 despite being able to lag behind many other countries chronologically (5).

Concerning that, there is no treatment available for the disease and no strategy available than supportive treatment; prevention and containment measures became crucial (6). Exponential growth of cases, the high proportion of patients with intensive care need and unavoidable deaths necessitated measures which were not planned at the beginning of the outbreak (7). Most of the precautions and restrictions of China, which were named "draconian" by western communities as quarantines and lock-downs had become standard policies of European countries (8). Countries with followed national or local lock-downs, school closures, meeting cancellations, travel restrictions and many other policies, with diverse densities and durations. Different perspectives and contradictions about types of reactions towards the spread of pandemic have reached a degree of reconciliation as cases and the number of deaths has increased. Although all sorts of precautions put into effect, some of the developed countries declared insolvency. Especially Italy and Spain reached the edge of their service capacity, despite their relatively robust healthcare systems and resources. Turkey started precautions similar to the European countries but in a timelier manner as flight cancellations, border controls, school cancellations, and took extraordinary measures such as a quarantine for senior and young people. Turkey reached the peak of the infection curve by a relatively low number of deaths and cases and did not confront a healthcare resources capacity problem.

The initial slow response, denial, and misplaced optimism in some of the European countries towards the pandemic caused anger and accusations (9). The pandemic has prompted a wide range of responses. All sorts of precautions were publicly discussed, whether they were effective and sufficient, because of socio-economic effects. While European countries easing back, lifting their restrictions thanks to flattening and falling infection rates curves (10), analyzing the effects of restriction would be vital.

The aim of this study is to explore the variation of stringency in government policies towards the spread of the outbreak and their effects on the spread of infection and destruction trend. The stringency of government policies of countries was analyzed together with their health system infrastructure and resources and the number of cases and deaths.

\section{MATERIAL and METHOD}

The research was designed as a comparative descriptive study, which aims to evaluate stringency degrees of government responses, number of cases and deaths and health system capabilities countries. The study consisted of four European countries (Italy, Spain, France, Germany, and United Kingdom) and Turkey, which were evaluated as more comparable concerning their geographic locations, close dates for first infection cases, and a similar degree of preparedness regarding healthcare systems.

Government Response Stringency Index (GRSI), which was created by Hale et al. to measure stringency of government measures against COVID-19, was used for the comparisons. The GRSI has been generated by tracking government interventions across a standardized series of indicators and transforming these ordinal, numeric, and text indicators to a composite index (11). Indicators 
that make up the stringency index are international travel bans, lockdowns, school closings, workplace closings, public event cancellations and gathering restrictions, public transport closings, stay at home requirements, and domestic travel limitations. A lower score of GRSI would indicate lower stringency of measures taken by governments towards COVID-19, while a higher score of GRSI indicates more stringent measures.

In order to compare countries' policies and their effects on case and death statistics, we initially aggregated daily stringency data of countries and compiled them with logistic numbers of cases and deaths. Thus, we could attain comparable visual trends of stringency of government policies and infection spread and loss. Furthermore, healthcare services resources, capabilities, and infrastructure were comparatively evaluated to discuss the possible causalities between precautions and effects.

\section{RESULTS}

The timeline of measures and reactions and their aggregated scores generated by GRSI have given the increase and decrease trends of stringency for all of the countries. Figures for the number of deaths by countries were also added to the graph. By that way, country comparison consisting of data such as interactions, number of deaths and cases could be made conveniently. An example of differences between policy interventions and the number of cases and deaths can be seen in Figure 1 for Italy and Turkey. The figure indicates that Italy had reached a higher number of cases and deaths, despite taking more stringent measures than Turkey.

Differences in policy responses of countries could be more apparent by decomposing the total stringency score to individual policy components, as seen in Figure 2. Observing the components of GRSI separately, the countries' patterns of response stringencies for each of the policy components could be revealed. The countries had preferred approximately the same sets of interventions with different stringency levels and durations. Results emphasize that Turkey had the same pattern with other countries in terms of school closing, public event cancelation, and domestic travel categories. Concerning public transport and stay at home requirement categories, Turkey achieves the highest score with Italy. While international travel is another component that Turkey shares the highest score with France and Spain, workplace closing and

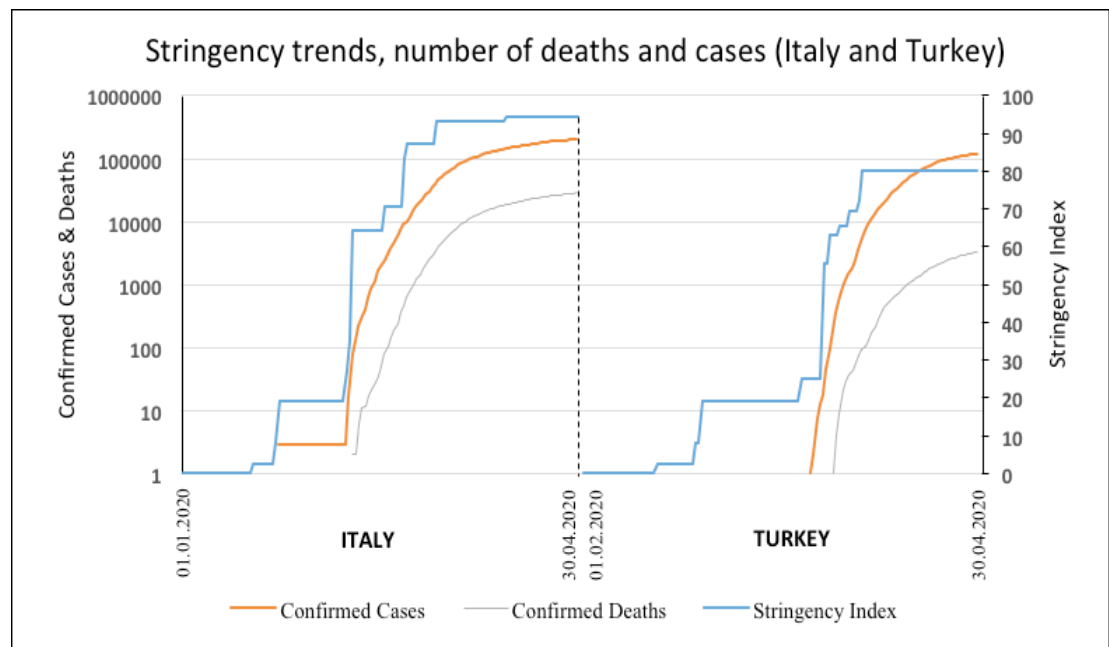

Figure 1. Stringency trends and number of case and deaths of Italy and Turkey 


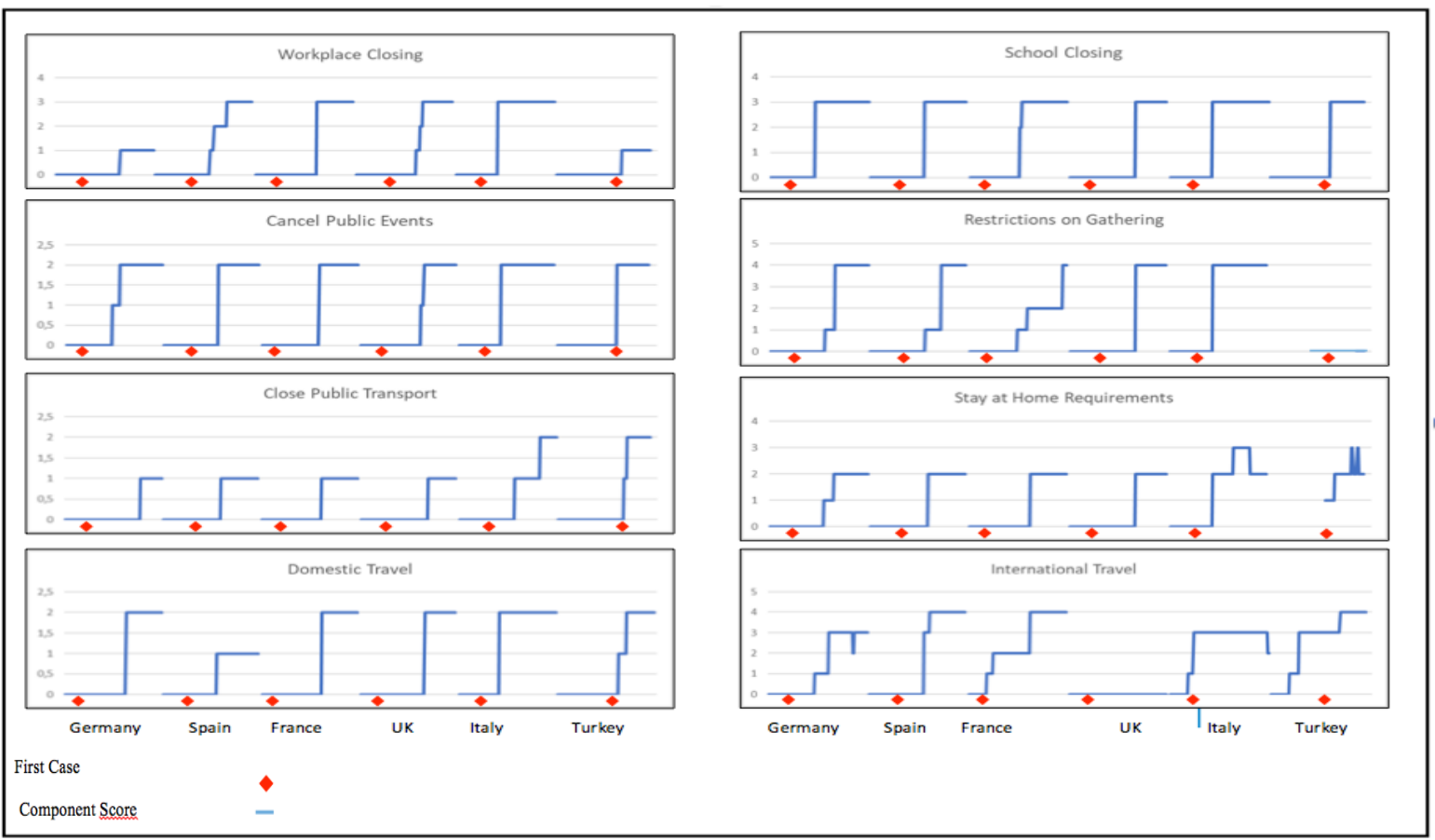

Figure 2. Patterns of Government Response Stringency Index (GRSI) for 6 Countries

restrictions on gathering are the lowest scores that Turkey places the last rank.

More importantly, after close investigation of countries' stringency patterns with first case dates, it can be observed that Turkey is diverse from any other country, having taken action before or concurrent with the first case (Figure 2). The other countries had taken the measures weeks after their first cases. Turkey was unique in taking immediate action with its first case. For the international travel restriction component, Turkey's response was even earlier (a month before the first case).

A total score of policy stringency for the entire period was calculated by aggregating scores for components. The total scores for intervention stringencies of each country were respectively: Italy $(6.694,98)$, France $(5.342,33)$, Spain $(4.993)$ Turkey $(4.585,02)$, Germany $(4.481,21)$ and United Kingdom $(4.090,73)$. Comparison between stringency index figures of countries indicated that; Turkey and
Germany were less stringent than Italy, Spain, and France. United Kingdom, which initiated its measures lately because of "herd immunity" approaches, had the least total stringency score.

Number of deaths and cases were included to analyze, to compare the effects of different types, durations and doses of policy interventions. Values generated from stringency index were matched with data for the number of deaths and cases per million (Figure 3 ). The number of cases per million population was higher than in other countries for Spain and Italy despite their more stringent measures. Turkey had the least cases per million value with relatively less stringent policies. The death toll per million population and stringency levels was higher for French, Italy, and Spain. Turkey and Germany seem to reach less number of deaths with less stringent measures. United Kingdom had the least stringent scores but a considerable number of deaths. 

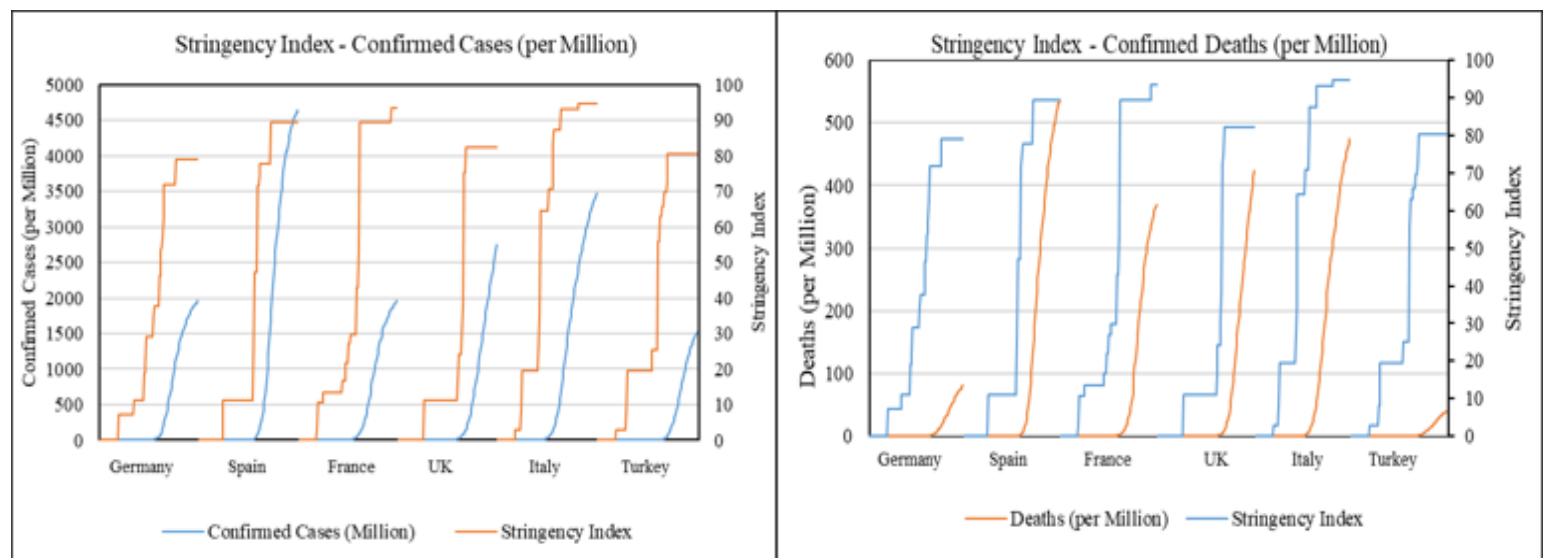

Figure 3. Government response stringency levels and number of deaths and cases (per million) for 6 countries

Turkey controlled case numbers and prevented the increase of death numbers while staying less stringent. Turkey had taken action earlier than other nations before the number of cases increased and reached relatively low degrees of stringency during the period until the beginning of May and the low number of cases and deaths. When we assess stringency scores with the number of cases, we could see similar trends. Figure 3 shows that Turkey is again less stringent with less number of cases.

Evaluating the stringency of countries' policy measures, figures for the number of deaths and cases, we can reach a result that; Turkey prevented the spread of disease and stopped the increase of death numbers with less stringent measures for the first period of pandemic.

\section{DISCUSSION}

The study described and compared measures taken by governments to prevent the spread of disease during the timeline from the first cases to the beginning of May 2020. The levels of policy stringency of countries were visualized for the timeline by using the Government Response Stringency Index (GRSI). Combining GRSI figures with the number of cases and deaths, it was possible to compare policy stringencies with spread trends on a daily basis.

Most of the countries adopted divergent approaches and perspectives about the disease, its spread character, level of risk and containment policy at the beginning of the period. Before the first cases, German government considered the spread of disease as "very low health risk" (22.01.2020) (12). The German Health Minister dismissed the closure of borders or direct flights between China and Germany, assessing unnecessary or inappropriate (02.03.2020) (13). UK adopted "herd immunity" perspective and decided to control, contain, and delay the infection spread without radical isolation measures until Imperial College report (16.03.2020) (14). Italy Foreign Minister Luigi Di Maio named the risk as "info-demic" which was hitting the country tourist flow and economy (28.02.2020) (15). On being compared to the other countries, Turkey had a more consistent and stabilized approach.

Interventions and responses varied in a wide range because of these different perspectives of governments.

Variation between countries in terms of COVID-19 policies started with international flight bans and airport health controls. Despite the forecasts about the spread risk via direct flights from Wuhan (16), United Kingdom acted reluctantly about suspending 
direct flights from Wuhan and China, which was resulted in widely criticizing the government for this policy (17). Germany insisted on not to apply health controls in airports. Germany and Spain did not ban flights from China until 16 March (18). Only Italy banned flights from China earlier (31 January) as soon as the first case emerged (19). Turkey started to use thermal cameras on 23 January and stopped flights from China on 05 February, more than a month before its first case.

Another example of variation between government policies would be lock-down decisions. Italy had to extend the lockdown measures to the entire country after implementing locally after reaching 9,172 cases and 463 number of deaths (09 March) (20). Spain imposed a nationwide lockdown on 14 March after confronting 7,988 cases and 294 deaths (21), France took the same decision two days after Spain on 16 March with 6.663 cases and 148 deaths (22). Finally, Germany and United Kingdom also following other countries. Germany took the decision on 22 March with 18,610 cases and a relatively low number of deaths (23). UK changed its "herd immunity and mitigation" perspective towards the pandemic after 16. March and had the lockdown decision while reaching 6,650 cases and 335 deaths on 23 March (24). Turkey also gave a more rapid response. Turkey took the lockdown decision with the first death and 47th case on 16 March 2020 (25).

While different perspectives towards pandemic have reached a degree of reconciliation, the number of cases and deaths has increased. Measures and interventions have almost become standard after confronting exponential growth of case numbers. Each of the countries imposed all sorts of interventions with some nuances during April. Differently, Turkey took action earlier than other nations before the number of deaths increased. The other countries (Italy, Spain, United Kingdom, France, Germany) had to impose more drastic measures nationwide for more extended periods. Inconsistency of perspective towards the outbreak and delay for implementation caused a need for more drastic measures for the next phases of intervention for those countries. Italy and Spain reached the edge of their service capacity, despite their relatively robust healthcare systems and resources, although they put into effect all sorts of precautions. Turkey had not even approximate to its' healthcare system capacity, although having relatively less stringent measures. Turkey has not implemented total lockdowns for long periods for all citizens. The lockdowns were imposed in an intermittent manner ( 2 weekends and a 4 day until the beginning of May). Also, lockdowns were not for all over the country but for metropolitan provinces. A unique policy for Turkey, stay in home requirements for seniors above the age of 65 (because of their vulnerability against the disease) and children and youngsters below the age of 20 (because of the probability of asymptomatic spread of virus) would be another point to emphasize.

The number of cases per million population was higher than in other countries for Spain and Italy despite their more stringent measures. The number of deaths per million population and stringency levels was higher for French, Italy, and Spain. Turkey had the least cases per million value with relatively less stringent policies. Turkey and Germany seem to reach less number of deaths with less stringent measures. United Kingdom had the least stringent scores but a considerable number of deaths. Turkey was able to control the number of cases and prevent the increase of death numbers while staying less stringent. Turkey had taken action earlier than other nations before the number of cases increased and reached relatively low degrees of stringency during the period until the beginning of May and the low number of cases and deaths.

While European countries and Turkey lifting their restrictions thanks to flattening and falling infection rates curves, it can be asserted that; Turkey reached the peak of the infection curve by a relatively low 
number of deaths and cases with less stringent government interventions and did not confront a healthcare resources capacity problem.

Observation of components of government responses emphasized that Turkey had the same pattern with other countries in terms of school closing, public event cancellation, and domestic travel categories. Turkey achieved the highest scores for public transport and stay at home requirement components with Italy and for international travel with France and Spain. For workplace closing and restrictions on gathering components, Turkey had the lowest scores. As a more important point to be emphasized, it could be observed that Turkey is diverse from any other country, having taken action before or concurrent with the first case. For the international travel restriction component, Turkey's response was a month before the first case.

In conclusion, we can reach the point that; Turkey was able to prevent the spread of disease and stop the increase in the number of deaths with less stringent measures. Turkey's rapid response as soon as the first case emerged and other countries' delayed responses because of contradictions and different perspectives would be one of the reasons behind this distinction. Based on the findings of this study, we suggest that adapting interventions and responses before the increase in the number of cases would contain the spread of infection lessen the response stringency level of the next phases and prevent bottlenecks for healthcare services. Comparison between intervention stringency levels and policy enforcement rapidity of selected countries highlighted the importance of implementation of measures on time. Further research for comparisons between government response stringencies, intervention types, timeliness implementation and their effects would be essential to have a better understanding of the expediency of policies and prepare for future potential pandemics. 


\section{REFERENCES}

1. Huang $C$, Wang $Y$, Li X, Ren L, Zhao J, Hu $Y$ et al. (2020). Clinical features of patients infected with 2019 novel coronavirus in Wuhan, China. Lancet, 2020; 395: 497-506, DOI: 10.1016/S01406736(20)30183-5.

2. Atlantic Council. Cover ups and incompetence, Iran as the Middle East's Coronavirus epicenter. Available from: https://www.atlanticcouncil.org/ blogs/iransource/cover-ups-and-incompetenceiran-as-the-middle-easts-coronavirus-epicenter/ Accessed in 09.05.2020.

3. Businnessinsider. Coronavirus pandemic timeline. Available from: https://www.businessinsider.com/ coronavirus-pandemic-timeline-history-majorevents-2020-3 Accessed in 09.05.2020.

4. CNBC. Europe is now the epicenter of the coronavirus pandemic, WHO says. Available from: https: / / www.cnbc.com/2020/03/13/europe-isnow-the-epicenter-of-the-coronavirus-pandemicwho-says.html Accessed in 09.05.2020.

5. Anadolu Agency. Latest on coronavirus outbreak: Turkey cofirms first case of coronavirus. Available from: https://www.aa.com.tr/en/latest-oncoronavirus-outbreak/turkey-confirms-first-caseof-coronavirus/1761522 Accessed in 09.05.2020.

6. Wu YC, Chen CS, Chan YJ. The Outbreak of Covid-19. Journal of the Chinese Medical Association, 2020; 83(3): 217-20, DOI: 10.1097/ JCMA. 0000000000000270 .

7. Remuzzi A, Remuzzi G. COVID-19 and Italy: what next? Lancet, 2020; 395: 1225-28 DOI: 10.1016/ S0140-6736(20)30627-9.

8. Editorial. COVID-19: learning from experience. Lancet, 2020; 395: 1011, DOI: 10.1016/S01406736(20)30686-3.

9. Editorial. COVID-19: learning from experience. Lancet, 2020; 395: 1011, DOI: 10.1016/S01406736(20)30686-3.

10. WeForum. The European Countries are starting to end their lockdowns. Available from: https://www. weforum.org/agenda/2020/04/these-europeancountries-are-starting-to-end-their-lockdowns/ Accessed in 09.05.2020.
11. Hale $T$, Noam A, Beatriz K, Anna P, Toby $P$, Samuel W. Variation in Government Responses to COVID-19, Version 5.0. Blavatnik School of Government Working Paper. 2020. Available from: www.bsg. ox.ac.uk/covidtracker Accessed in 09.05.2020.

12. RP-Online. Neues Virus kein Grund für Alarmismus. Available from: https://rp-online.de/panorama/ ausland/bundesregierung-coronavirus-nurgeringes-gesundheitsrisiko-in-deutschland_aid48488333 Accessed in 09.05.2020.

13. Tagesschau. Coronavirus Deutschland. Available from: https://www.tagesschau.de/inland/ coronavirus-deutschland-153.html Accessed in 09.05.2020.

14. Imperial College COVID-19 Response Team. Impact of non-pharmaceutical interventions (NPIs) to reduce COVID19 mortality and healthcare demand. Available from: https://www.imperial.ac.uk/ media/imperial-college/medicine/sph/ide/ gida-fellowships/Imperial-College-COVID19-NPImodelling-16-03-2020.pdf, Accessed in 09.05.2020.

15. $A B C$ News, Italy virus count methods agencys urging, Available from: https://abcnews.go.com/ Health / wireStory/italy-virus-count-methodsagencys-urging-69254949, Accessed in 09.05.2020.

16. Wu JT, Leung $\mathrm{K}$, Leung GM. Nowcasting and forecasting the potential domestic and international spread of the 2019-nCoV outbreak originating in Wuhan, China: a modelling study, Lancet 2020; 395: 689-97, DOI: 10.1016/S0140-6736(20)30260-9.

17. Technical Politics. Too weak, too slow: The UK Governments dithering response to Wuhan coronavirus increases the risk of majör loss of life. Available from: https://www.technicalpolitics. com/articles/too-weak-too-slow-the-ukgovernments-dithering-response-to-the-wuhancoronavirus-increases-the-risk-of-major-loss-oflife/, Accessed in 09.05.2020.

18. Welt. Wirtschaft. Available from: https://www. welt.de/wirtschaft/article206638213/CoronavirusFlug-IR721-enttarnt-Scheuers-Landeverbot-alsleeres-Versprechen.html, Accessed in 09.05.2020. 
19. CNN. Coronavirus outbreak. Available from: https: / / edition.cnn.com/asia/live-news / coronavirus-outbreak-01-31-20-intl-hnk/h_ ed756d2007470c7fb4eeb4492bafabf5, Accessed in 09.05.2020.

20. BBC. News. Available from: https://www.bbc. com/news/world-europe-51810673, Accessed in 09.05.2020.

21. National Post. Spain imposes national lock down. Available from: https://nationalpost.com/ $\mathrm{pmn} /$ health-pmn/spain-to-impose-nationwidelockdown-el-mundo, Accessed in 09.05.2020.

22. Independent. Coronavirus France lockdown cases update. Available from: https://www. independent.co.uk/news/world/europe / coronavirus-france-lockdown-cases-update-covid19-macron-a9405136.html, Accessed in 09.05.2020.
23. Welt. Kontaktverbote zu mehr als zwei Personen, Friseure zu - Darauf haben sich Bund und Länder geeinigt. Available from: https://www.welt. de/politik/deutschland/article206725829/ Coronavirus-Deutschland-Kontaktverbote-zu-mehrals-zwei-Personen-Friseure-zu.html, Accessed in 09.05.2020.

24. The Guardian. Boris Johnson adress to the nation. Available from: https://www.theguardian.com/ uk-news/2020/mar/23/boris-johnsons-address-tothe-nation-in-full, Accessed in 09.05.2020.

25. Anadolu Agency. İçișleri Bakanlığından koronavirus tedbirleri genelgesi. Available from: https://www. aa.com.tr/tr/koronavirus/icisleri-bakanligindankoronavirus-tedbirleri-genelgesi/1768059, Accessed in 09.05.2020. 